\title{
10. Transferring the acquis through EU agencies: the case of the European Neighbourhood Policy countries
}

\section{Dovilė Rimkutė and Karina Shyrokykh}

\section{INTRODUCTION}

One of the key features of the evolution of the 'European regulatory state' has been 'agencification'. 'To date, more than 40 decentralized EU agencies and bodies support EU institutions and Member States in making and implementing European regulations. Such institutional processes have significantly affected the nature of the EU regulatory state, as well as the means of setting standards within the internal market.

EU agencies are actively involved not only in shaping the regulatory landscape of the EU, but also in building the EU regulatory state beyond its borders through a dense net of transgovernmental ties that extend to third-country regulators. ${ }^{2}$ In particular, EU agencies focus on institution building and advancing the state capacity of third countries to bring their regulatory standards closer to the EU norms. ${ }^{3}$ A recent contribution by Lavenex provides one of the first assessments of the EU's regulatory governance in third countries. She demonstrates that non-Member States have an opportunity to align themselves with the standards of the EU and benefit from the 'access to a plethora of committees and regulatory agencies that contribute to the development and

1 See Madalina Busuioc, Martijn Groenleer and Jarle Trondal, The Agency Phenomenon in the European Union: Emergence, Institutionalisation and Everyday Decision-Making (Manchester, MUP 2012); see also Arndt Wonka and Berthold Rittberger, 'Credibility, Complexity and Uncertainty: Explaining the Institutional Independence of 29 EU Agencies', [2010] WEP 4 730, 730-752.

2 See Sandra Lavenex, 'The External Face of Differentiated Integration: Third Country Participation in EU Sectoral Bodies', [2015] JEPP 6 836, 836-853.

3 See Rimkute and Shyrokykh, 'The Role of EU Agencies in the Acquis Transfer: The Case of the European Neighbourhood Policy Countries', [2017] TARN Working Paper Series 14 1, 1-19. 
implementation of EU policies'. ${ }^{4}$ She also illustrates that such integration has a differentiated character in contributing to the spread of the acquis (ie, EU legislation and regulation) in third countries. More precisely, various EU agencies are open to the participation of third countries, both at different points in time and to a different extent.

Building upon existing scholarly work, this chapter aims to systematically map and explain the variance across agencies' openness to participation of the European Neighbourhood Policy (ENP) countries. We aim to examine whether the external dimension of EU agencies' inclusion reflects the pursuit of the overarching EU foreign policy objectives as stated in Article 21 of the Treaty on European Union and/or echoes the objectives dictated by the need to find common solutions in the policy domains marked by high interdependencies. Empirically, the chapter concentrates on all EU agencies involved in all ENP states. The period of investigation covers ten years (2007-17). The analysis builds upon primary sources and information provided by the European Commission and EU agencies. Empirical analysis reveals that sector-specific interdependencies explain EU agencies' engagement patterns with the ENP countries.

The chapter contributes to the scholarship of the external dimension of EU agencies in two ways. The EU agency phenomenon has received much scholarly attention: ${ }^{5}$ the role that EU agencies play internally in the multi-level arrangements ${ }^{6}$ and how they impact on the functioning of the internal market have been explored. ${ }^{7}$ However, our understanding of the regulatory outreach of EU agencies beyond the EU's borders is rather limited and only recently started to receive scholarly attention. ${ }^{8}$ We know very little of the extent to which EU agencies are involved in the EU's external governance and the ways in which they contribute to this domain. This chapter, therefore, first undertakes a systematic explanation of EU agencies' external outreach.

4 Lavenex, supra note 2, 850.

5 For an overview, see Morten Egeberg and Jarle Trondal, 'Researching European Union Agencies: What Have We Learnt (and Where Do We Go from Here)?', [2017] JCMS 4 675, 675-690.

${ }^{6}$ See Eva Heims, 'Regulatory Co-ordination in the EU: A Cross-Sector Comparison', [2017] JEPP 8 1116, 1116-1134; see also Emmanuelle Mathieu, Regulatory Delegation in the EU: Networks, Committees and Agencies (London, Palgrave Macmillan, 2016); see also Jarle Trondal and Lene Jeppesen, 'Images of Agency Governance in the European Union', [2008] WEP 3 417, 417-441.

7 See Herwig Hofmann, 'European Regulatory Union? The Role of Agencies and Standards', in Panos Koutrakos and Jukka Snell (eds), Research Handbook in Internal Market Law (Cheltenham, Edward Elgar, 2017), 460.

${ }_{8}$ See also the chapters by Helena Ekelund and Merijn Chamon and Valerie Demedts in this book. 
Additionally, existing literature on the external dimension of EU agencies is predominantly based on single case studies or small- $n$ comparisons. ${ }^{9}$ Thus, this chapter's second contribution is a comparative assessment of all of the EU agencies that cooperate with the ENP countries. By providing a systematic and holistic perspective on supranational agencies' involvement in the EU's neighbourhood, this study describes the variance in the agencies' outreach across policies and states.

The remainder of this chapter is organized as follows. First, we briefly introduce the empirical phenomenon of interest - namely, the external dimension of the EU agencies. Second, we review relevant literature and introduce two explanations that we expect to account for the variance in the agencies' involvement in the ENP region. The third section discusses the core findings on the involvement of EU agencies in the transfer of the EU acquis to the ENP region. Lastly, in the concluding section, we summarize the contribution of this chapter and indicate avenues for future research.

\section{EU AGENCIES IN THE ENP COUNTRIES}

In 2004, the European Commission stated that ENP states are eligible to participate in EU programmes that are 'in the interest of the enlarged EU and neighbouring countries'. ${ }^{10}$ The EU declared its commitment to develop a close relationship with 16 neighbouring countries: Algeria, Armenia, Azerbaijan, Belarus, Egypt, Georgia, Israel, Jordan, Lebanon, Libya, Moldova, Morocco, Syria, Palestine, Tunisia and Ukraine. The ENP envisioned 'the gradual opening of certain Community programmes, based on mutual interests and available resources'. ${ }^{11}$ Participation in specific programmes aims to contribute towards the development of administrative and state capacity needed for effective cooperation and reaching common goals. Through the ENP, the EU seeks to ensure stability, security, prosperity and good governance in its neighbour-

9 See Florin Coman-Kund, 'The International Dimension of the EU Agencies Charting a Legal-Institutional "Twilight Zone"', [2017] TARN Working Paper Series 5 1, 1-22; see also Martijn Groenleer and Simone Gabbi, 'Regulatory Agencies of the European Union as International Actors: Legal Framework, Development over Time and Strategic Motives in the Case of the European Food Safety Authority', [2013] EJRR 4 479, 479-492.

10 European Commission, 'European neighbourhood policy: strategy paper', COM (2004) 373 final, Brussels, 4.

11 European Commission, 'General approach to enable ENP partner countries to participate in Community agencies and Community programmes', COM (2006) 724 final, Brussels, 3. 
ing countries and thus subsequently ensure its own prosperity and security. ${ }^{12}$ The organizational opening of EU agencies to the ENP countries evidently contributes to this goal.

In 2007 the Council of the European Union approved the participation of the ENP countries in the activities of some EU agencies. The participation of the ENP partner countries in the work of the EU decentralized agencies is regarded as a key element of the ENP instrument. Such a partnership is based on the agreement between a specific EU agency and an interested ENP partner country. The core precondition for the participation of the ENP country in EU agencies' activities is based on the merits of the progress of the third countries - that is, the implementation of sector-specific reforms and compliance with EU technical standards (European Commission 2011). As a result, involvement in the activities of EU agencies infers integration in the regulatory framework of the EU and is an instrument for approximation to EU norms and standards.

More than 20 EU agencies are open for participation by ENP partner countries. Collaboration between EU agencies and the ENP partner countries can manifest in two forms: (1) ad hoc arrangements (temporary project-based technical or scientific cooperation) and/or (2) special bilateral arrangements signed between two parties and henceforth establishing a sustained institutionalized link between an EU agency and an ENP country. According to the first format, the ENP states can gain access to the activities of EU agencies on an ad hoc basis - for example, various short-term arrangements aimed at institution and technical capacity building. They are organized via the Technical Assistance and Information Exchange (TAIEX) tool or via other programmes managed by the Directorate-General for Neighbourhood and Enlargement Negotiations of the European Commission (DG NEAR). EU agencies thus have an opportunity to support the approximation, application and implementation of EU legislation in the ENP region. For instance, participation in TAIEX activities is aimed at facilitating the delivery of tailor-made expertise to address issues that are relevant to individual ENP countries. ${ }^{13}$ Within this setting, the primary beneficiary group is civil servants from ENP countries operating at national, subnational or local levels. TAIEX provides a platform for EU agencies to share their technical and scientific expertise in all fields of the EU acquis, such

12 European Commission, 'Wider Europe-Neighbourhood: A New Framework for Relations with Our Eastern and Southern Neighbours', COM (2003) 104 final, Brussels.

13 Karina Shyrokykh, 'Policy-Specific Effects of Transgovernmental Cooperation: A Statistical Assessment across the EU's post-Soviet Neighbours', [2019] JEPP 1 149, 149-168. 
as justice and home affairs, internal market, environment, agriculture, food safety and transport (including the aviation, maritime and railway sectors).

The second format of cooperation stipulates that EU agencies can propose bilateral cooperation to third countries and establish institutionalized ties by signing formal working/strategic/technical/operational arrangements with an individual ENP country. These formal working arrangements are often restricted to technical collaboration underlining the capacity-building function, as seen in the example of EU enlargement.

Within the existing legal framework, EU agencies can employ various forms of cooperation, be they ad hoc arrangements, bilateral working agreements or a combination of both. Studies focusing on a small sample of EU agencies (ie, the European Chemicals Agency, the European Food Safety Authority, the European Environmental Agency, Frontex and Europol) suggest that EU agencies are open to participation of third countries at different points in time, to a different extent, and that they propose various forms and combinations of cooperation to the different groups of the ENP states. ${ }^{14}$ Building on this observation, this study aims to explain the patchy patterns of cooperation between EU agencies and the ENP countries across policy sectors, agencies and countries.

\section{THEORETICAL FRAMEWORK: FOREIGN POLICY OBJECTIVES VERSUS SECTOR-SPECIFIC INTERDEPENDENCIES}

In studies investigating external governance of the EU towards third countries, major attention is usually paid to the material leverage of the EU to impact third states' behaviour. ${ }^{15}$ For instance, studies highlight the role played by conditionality attached to reforms in various sectors. The economic leverage is, in fact, significant, since the EU is a prominent economic actor. More recent literature, however, has started to pay attention to the fact that the EU may wield influence not just by leverage, but also by disseminating practices, norms and ideas. ${ }^{16}$ Existing scholarly work demonstrates that the EU's techni-

\footnotetext{
14 Lavenex, supra note 2.

15 See Frank Schimmelfennig, 'Strategic Calculation and International Socialization: Membership Incentives, Party Constellations, And Sustained Compliance in Central and Eastern Europe', [2005] IO 4 827, 827-860; see also Antoaneta Dimitrova and Rilka Dragneva, 'Shaping Convergence with the EU in Foreign Policy and State Aid in post-Orange Ukraine: Weak External Incentives, Powerful Veto Players', [2013] Europe-Asia Studies 4 658, 658-681.

${ }_{16}$ See Julia Langbein and Kataryna Wolczuk, 'Convergence without Membership? The Impact of the European Union in the Neighbourhood: Evidence from Ukraine',
} 
cal assistance via various capacity-building instruments is an effective tool to promote legislative convergence and diffuse best practices. In addition to this, it can also impact on the democratic attitudes of public servants and in turn foster democratic change. ${ }^{17}$ This scholarship focuses on transgovernmental networks and the role they play. Networks established between public servants in Member States and the ENP countries focus on problem and sector-specific cooperation and are limited to a participation of professionals with recognized knowledge, expertise and competence in a specific policy domain or issue area. They stimulate the transfer of knowledge, which in turn may induce a change in third countries. ${ }^{18}$

Instead of focusing on the effects of such cooperation, this study addresses the variance existing in the degree of cooperation between EU agencies and the ENP states, which the literature relating to the external dimension of EU governance has so far not sufficiently explained. A recent contribution of Lavenex (2015) proposes a very first appraisal of the EU agencies' involvement in third countries, describing the variance in cooperation across seven EU agencies. We build on this contribution, but extend our focus to all EU agencies that are involved in the EU's external governance activities in the ENP region.

Existing scholarly work suggests that the core drivers of the external differentiation of EU governance in the neighbouring regions are either foreign policy objectives in the region and/or functional interdependencies that require effective cooperation for successful problem-solving. ${ }^{19}$ We tailor these explanations to examine the role of EU agencies in the context of the ENP states.

The foreign policy objectives are predominantly political and are aimed at serving the general interests of the EU. In this logic, the inclusion of the ENP countries in EU agency activities is not an objective per se, but rather serves as a foreign policy tool that is aimed at advancing the acquis of the EU. ${ }^{20}$ Thus, the core aims of the inclusion of the ENP countries in EU agency activities is

[2012] JEPP 6 863, 863-681; see also Sandra Lavenex, 'A governance Perspective on the European Neighbourhood Policy: Integration beyond Conditionality?', [2008] JEPP 6 938, 938-955; see also Tina Freyburg, 'Transgovernmental Networks as Catalysts for Democratic Change? EU Functional Cooperation with Arab Authoritarian Regimes and Socialization of Involved State Officials into Democratic Governance', [2011] Democratization 4 1001, 1001-1025.

${ }_{17}$ See Shyrokykh, supra note 13; see also Tina Freyburg, 'Transgovernmental Networks as an Apprenticeship in Democracy? Socialization into Democratic Governance through Cross-National Activities', [2013] ISQ 1 59, 59-72.

18 Shyrokykh, supra note 13.

19 Lavenex, supra note 2; see also Frank Schimmelfennig, Dirk Leuffen and Berthold Rittberger, 'The European Union as a System of Differentiated Integration: Interdependence, Politicization and Differentiation', [2015] JEPP 6 764, 764-782.

20 Lavenex, supra note 2 . 
to prepare third countries for further integration with the EU, acquaint them with the acquis or signal a symbolic recognition by and acceptance into the European community.

The foreign policy perspective views cooperation between the ENP countries and EU agencies as one of the avenues to further extend the regulatory and territorial boundaries of the EU. ${ }^{21}$ To that end, EU agencies support the European Commission in promoting its core foreign policy agenda to enhance regional stability, strengthen liberal democratic values and foster regional economic wellbeing through third countries' approximation to the EU acquis. ${ }^{22}$

EU agencies are a part of a broader hierarchical chain supporting EU institutions in achieving their wider objectives. In line with this reasoning, the expectation is that the decision to grant the access to EU agencies' activities for the ENP country is based on the integration status of the country. That is, from the foreign policy perspective, one would expect the deepening cooperation between an EU agency and an ENP country to be a result of the country's integration attempts and status (rather than a result of sector-specific functional interdependencies). In this way, patterns of cooperation should mimic the level of integration. Hence, in accordance with this logic, we expect EU agencies to engage in various forms of cooperation with the ENP countries following these countries' association stage with the EU. The organizational inclusion of the ENP countries in EU agencies' undertakings should echo formal pledges to the EU acquis. The domestic pre-existing differences of the ENP countries - in terms of their regulations or administrative capacities - should be less important for granting access to the participation in EU agencies' activities because the core goal of such inclusion is to foster approximation to the EU acquis. Hence, we expect that:

Foreign Policy Hypothesis (H1): Cooperation between EU agencies and the ENP partner countries follows the patterns of the ENP countries' integration status with the EU.

If this 'foreign policy' hypothesis holds, we should empirically observe the variance in agencies' involvement across different groups of countries rather than across policy domains. The integration status of an ENP country should be a core factor defining the extent to which EU agencies are open to the ENP states. By 'integration status', we mean the depth of the relations between the EU and an ENP state - exemplified, for instance, by the conclusion of an Association Agreement, such as those with Ukraine (2017), Georgia (2016),

21 Lavenex, supra note 2.

22 European Commission, supra note 11. 
Moldova (2016), Israel (2000), Tunisia (1998), Algeria (2005), Egypt (2004), Jordan (2002), Lebanon (2006) and Morocco (2000). Negotiations for such Association Agreements have also been conducted with Armenia (suspended since 2013), Azerbaijan, Libya (suspended since 2011) and Syria (suspended since 2011). There have been no negotiations with Belarus, due to its domestic practices that pose threats to the EU's core democratic values. If this hypothesis holds, we expect to observe that countries in more advanced stages of integration (ie, Association Agreements have been signed) are given greater access to EU agency activities. On the contrary, in countries that are in the less advanced phase of Association Agreements, we expect to observe only limited access to EU agencies' activities. In other words, we expect this variation to be present across states, rather than policy fields.

A functionalist perspective proposes a different explanation. From the functional interdependencies perspective, EU agencies provide expertise in key areas of mutual interest. Such transgovernmental networks between the EU and neighbouring states facilitate acquis transfer and regulatory convergence. ${ }^{23}$ They have been featured as functional bodies shaping the Europeanization of neighbouring states, ${ }^{24}$ often operating as hubs or scientific communities bringing together supranational and national experts. ${ }^{25}$

From the functional interdependencies perspective, openness of EU agencies to participation of ENP states does not follow the 'top-down' patterns of the EU foreign policy objectives. Instead, it follows 'bottom-up' dynamics and originates from functional interdependence in a specific sector. ${ }^{26}$ The functional interdependencies logic suggests that cooperation between EU agencies and the ENP partner countries reflects policy-specific patterns of interdependence rather than broad foreign policy objectives. In other words, it is not an ENP country's position vis-à-vis the EU that induces access to EU agencies, but rather policy-specific functional needs to jointly address common problems.

\footnotetext{
23 Shyrokykh, supra note 13.

24 Lavenex, supra note 2; Shyrokykh, supra note 13.

25 See Burkard Eberlein and Abraham L Newman, 'Escaping the International Governance Dilemma? Incorporated Transgovernmental Networks in the European Union', [2008] Governance 1 25, 29; see also Martino Maggetti and Fabrizio Gilardi, 'Network Governance and the Domestic Adoption of Soft Rules', [2014] JEPP 9 1293, 1293-1310; see also Emmanuelle Mathieu, 'When Europeanization Feeds Back into EU Governance: EU Legislation, National Regulatory Agencies, and EU Regulatory Networks', [2016] PA 1 25, 25-39; see also Kutsal Yesilkagit, 'Institutional Compliance, European Networks of Regulation and the Bureaucratic Autonomy of National Regulatory Authorities', [2011] JEPP 7 962, 962-979.

26 Lavenex, supra note 2 .
} 
To define the level of interdependence between the EU and ENP states, we rely on the international cooperation model introduced by Botcheva and Martin, ${ }^{27}$ who argue that two parties considering cooperation aim to tackle collective action problems. Botcheva and Martin further argue that the level of international cooperation depends on the certain issues being addressed, as different policy sectors are marked by different level of externalities. ${ }^{28}$ As a result, the first step in identifying the level of independence is to look at the level of externalities of the specific policy area that two parties aim to address. In the case of high externalities of non-cooperation, two parties will aim to establish strong ties because in this way states can address common action problems better. In this case, states benefit from cooperating, as it increases the pay-offs for both. This in turn leads to higher interdependencies in policy areas that are marked by higher externalities of non-cooperation. In contrast, in the case of low externalities of non-cooperation, the outcome of one party is not affected by the choices of the other. Policy failures in a neighbouring country are unlikely to affect a situation in an EU Member State. Consequently, in policy sectors marked by such lower externalities, we expect lower interdependencies and thus less intense cooperation.

In accordance with this logic, the expectation would be that cooperation between EU agencies and the ENP countries follows the pattern of sector-specific dynamics (ie, sectoral interdependence). We expect to observe the EU granting access to the ENP countries in policy areas where there is greater sectoral interdependence. We expect that the increase of interdependencies in specific policy domains creates a necessity for cross-national cooperation to resolve common issues by utilizing formal and informal means. ${ }^{29}$ Thus, the functional interdependence hypothesis reads as follows:

Functional Interdependence Hypothesis (H2): Cooperation between EU agencies and the ENP partner countries follows the patterns of sector-specific interdependencies.

In line with this reasoning, one would expect to observe that EU agencies working in fields marked by higher interdependencies (high externalities of non-cooperation) are more involved in the external dimension of EU governance. That is, EU agencies in the interconnected issue areas (eg, border control,

27 Liliana Botcheva and Lisa Martin, 'Institutional Effects on State Behavior: Convergence and Divergence', [2001] ISQ 1 1, 1-26.

28 Ibid.

29 See Henry Farrell and Abraham L Newman, 'Domestic Institutions beyond the Nation-State: Charting the New Interdependence Approach', [2014] World Politics 2 331, 331-363. 
migration, transportation, and drug and human trafficking) will be more open to cooperation than EU agencies working in policy areas marked by lower interdependencies (lower externalities of non-cooperation) (eg, social regulation issues such as food safety, chemicals and pharmaceuticals).

To test these hypotheses, the study draws on the analysis of primary documents of the European Commission and EU agencies (eg, internal policy documents, register of events, cooperation agreement/arrangements, Association Agreements). First, relying on systematic desk research, we map the cooperation practices between EU agencies and the ENP countries. Second, to obtain this data, we contacted all EU agencies requesting them to confirm the status and forms of their cooperation with each of the ENP countries. All of the agencies responded to our request either by confirming the findings of our desk research or by providing additional information and clarifications regarding their external activities.

\section{MAPPING THE ROLE OF EU AGENCIES IN THE EUROPEAN NEIGHBOURHOOD POLICY}

In this section, we describe and explain the extent to which individual EU agencies are involved in EU external governance. Furthermore, we explore whether the variance in EU agency openness to the ENP countries follows the broad foreign policy objectives $(H 1)$ or is rather rooted in the (sector-specific) functional interdependence considerations $(\mathrm{H} 2)$.

The EU agencies' involvement in the ENP region varies considerably across agencies (see Figure 10.1). Some EU agencies have both ad hoc and institutionalized cooperation arrangements with the ENP states, while others only recently started to engage in sporadic ad hoc arrangements. Furthermore, different agencies became involved in the external dimension of EU governance at different points in time. The entire population of agencies can be assigned to three different groups regarding their role and engagement with the ENP partner states: (1) a group representing a higher degree of cooperation of agencies, which combines both of the means of interaction with the neighbouring states (ie, $a d$ hoc and institutionalized arrangements); (2) a group representing moderate cooperation of agencies, which predominantly focuses on the ad hoc arrangements; and (3) a group representing a lower extent of cooperation with agencies, which is not involved with the ENP states even though the Council of the European Union has given approval for such cooperation. The following section systematically describes each of these three groups. 


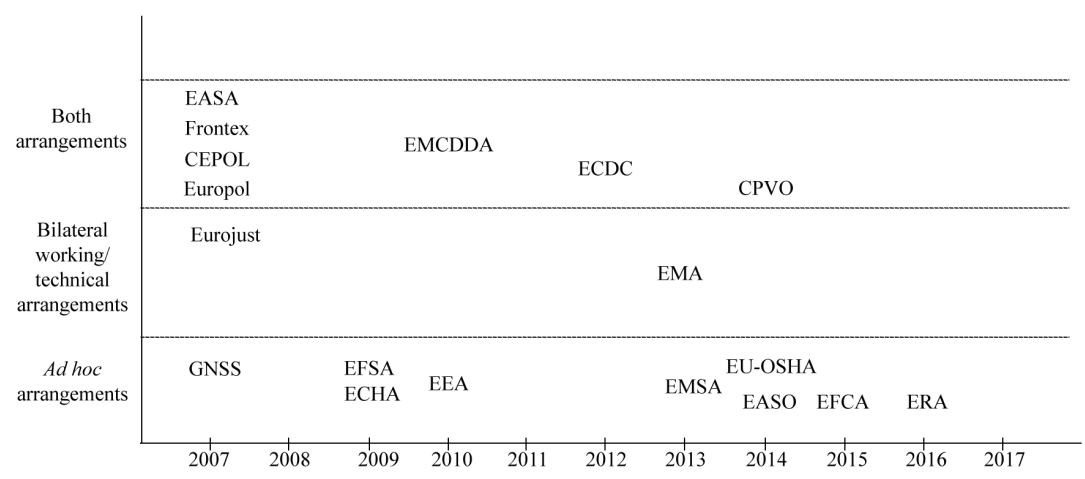

Figure 10.1 The external dimension of EU agencies: types of cooperation

\subsection{Highest Level of Cooperation}

The analysis reveals that the most engaged EU agencies are the European Union Aviation Safety Agency (EASA), Frontex, Europol, the European Union Agency for Law Enforcement Training (CEPOL) and the European Monitoring Centre on Drugs and Drug Addiction (EMCDDA) (see Figure 10.1). The five agencies propose both forms of cooperation to the ENP countries: ad hoc cooperation activities and bilateral working arrangements. Furthermore, in terms of timing, the five agencies can be regarded as 'early birds', as they were the first to open for cooperation with the ENP states. This empirical observation gives strong support to the functional interdependence hypothesis, as all five agencies work in the policy areas that are marked by high interdependencies between the EU and the ENP partner countries. Four out of these five EU agencies work closely with the ENP partner countries (ie, Frontex, Europol, CEPOL and the EMCDDA) and contribute to the policies of Justice and Home Affairs. In the Justice and Home Affairs configuration, interdependencies are highest, as this includes issues such as border control, immigration flows and drug trafficking, which require joint problem solving. All five EU agencies are focused on capacity building and on establishing strong institutional ties with the ENP countries, as demonstrated in the discussion that follows.

EASA cooperates widely with authorities in the ENP partner countries in order to raise their regulatory standards in the aviation safety domain. EASA aims to support the implementation of comprehensive Aviation Agreements, and seeks to develop common safety standards and procedures, as well as to further foster cooperation between EASA and the ENP countries themselves. Working agreements signed between EASA and the authority of an ENP 
country exclusively cover issues of a technical nature. ${ }^{30}$ EASA has already signed arrangements with Armenia, Azerbaijan, Georgia, Israel, Moldova, Morocco and Ukraine. Besides its more institutionalized ties with the ENP countries, EASA continuously arranges ad hoc technical cooperation projects (eg, Transport Corridor Europe-Caucasus-Asia (TRACECA) and the Euro-Mediterranean Partnership). The projects are carried out in close cooperation with local ENP authorities and stakeholders, and are aimed at advancing regulatory and oversight competences of national aviation authorities.

In a similar vein, Frontex, CEPOL and Europol offer many opportunities for cooperation (both ad hoc and bilateral arrangements). For instance, cooperation with third countries is a fundamental part of the formal mandate of Frontex. The agency claims that 'building external relations is a valuable tool for effectively handling irregular migration and cross-border crime in accordance with EU's Integrated Border Management (IBM) strategy'. ${ }^{11}$ Moreover, Frontex continuously works on developing and maintaining close cooperation with the authorities of third states. The partnerships are usually established with the law enforcement authorities responsible for border control to work towards effective border management capacities. Frontex emphasizes that its highest priority is to create firm technical cooperation with immediate neighbours, as well as with those third countries bordering the southern neighbourhood countries. Frontex has signed working arrangements with the authorities of five ENP countries: Ukraine, Moldova, Georgia, Belarus, Armenia and Azerbaijan. The agency is in various negotiation stages of discussions with the authorities of Libya, Morocco, Egypt and Tunisia.

Furthermore, Frontex oversees several technical assistance projects in non-EU countries via the TAIEX tool managed by the European Commission. Frontex liaises with the ENP partner countries in the areas of information exchange, research and development, risk analysis, training, pilot projects and joint operations. Examples include initiatives such as the Migration and Mobility Partnerships, the Eastern Partnership (EaP) Initiative and the Building Migration Partnerships. ${ }^{32}$ The latter projects, for instance, support the realization of IBM across borders of the EaP countries - Armenia, Azerbaijan, Belarus, Georgia, Moldova and Ukraine. The project aims to provide training individually tailored to the specific needs of beneficiaries to 'facilitate smooth

30 See Florin Coman-Kund, European Union Agencies as global actors - a legal study of the European Aviation Safety Agency, Frontex, and Europol (Maastricht, Universitaire Pers Maastricht, 2015).

31 See Frontex, 'Third Countries', (2017), http://frontex.europa.eu/partners/third -countries/, last accessed 25 October 2018.

32 Ibid, 31. 
border crossing for legitimate travel and trade and at the same time to prevent cross-border crime'. ${ }^{33}$

In addition, Frontex works together with the European Asylum Support Office (EASO) to support the external dimension of the Common European Asylum System, engage with third countries to reach common solutions and provide third countries with capacity-building and regional protection programme. For instance, EASO has implemented an ENPI project (2014-16) with Jordan, Tunisia and Morocco. The core objective of the project was to familiarize officials from Tunisia, Morocco and Jordan with the mandate of EASO and Frontex, and to introduce the tools and instruments that the two EU agencies use. EASO aimed to assess the technical needs of the three countries in order to provide them with suitable tools to support capacity building to respond to these needs.

CEPOL and Europol cooperate with the relevant bodies of the ENP countries in the field of law enforcement. Corresponding capacity building targeting police authorities in third countries is a priority of CEPOL. To that end, CEPOL is regularly involved in regional training activities. In these activities, CEPOL works together with Europol; however, Europol focuses mostly on the ENP countries that have signed cooperation agreements (Moldova, Ukraine and Georgia), while CEPOL engages in various ad hoc arrangements with all ENP partner countries. CEPOL is an active contributor to TAIEX activities, where it oversees the regional MEDA/MEDA JAI programmes and the European Police Exchange programmes. It regularly provides workshops targeting the national law enforcement agencies from the ENP countries on issues such as police conduct and use of powers, police activity in a democracy, cross-border police cooperation, management and police ethics, police activity in a democracy, police conduct and use of powers, as well as combating cyber-terrorism.

In its training activities, CEPOL cooperates with Eurojust. Eurojust representatives provide training at CEPOL courses, seminars and conferences on a regular basis. Besides these ad hoc demand-driven arrangements, CEPOL has concluded a cooperation agreement with Georgia and has signed working arrangements with Armenia and Moldova. Meanwhile, Eurojust has signed cooperation agreements with Moldova and Ukraine.

Among the most engaged EU agencies is the EMCDDA. The EMCDDA's cooperation with the ENP countries ranges from coordination of technical ad hoc assistance projects to consultative support and training. The core objective of such cooperation is to share the EMCDDA's monitoring practices, data collection tools and guidelines, as well as to assist the ENP countries in creating

33 Ibid, 31. 
their own national drug information systems. The EMCDDA cooperates with the ENP countries to exchange data and methodologies for monitoring the drug situation and organizing joint training activities. Almost all ENP countries are participants in the EMCDDA's ad hoc activities which are implemented through the TAIEX tool. The core objective of the EMCDDA's ad hoc arrangements is to strengthen the capacity of ENP partner states to respond to emerging challenges and the most recent developments of the drugs situation. Four ENP countries have already signed a memorandum of understanding with the EMCDDA: Ukraine, Moldova, Israel and Georgia.

The European Centre for Disease Prevention and Control (ECDC) aims to establish technical cooperation on the prevention and control of communicable diseases. ${ }^{34}$ Its long-term objective is to create a set of procedures and tools for technical cooperation with the ENP countries and establish well-functioning contacts for cooperation. The ECDC, however, has signed a Memorandum of Understanding and an Administrative Agreement solely with Israel.

The aforementioned patterns of cooperation between EU agencies and the ENP partner countries support the functional interdependence hypothesis suggesting that agencies fulfil roles dictated by higher externalities. That is, EU agencies related to the fields marked by higher sector-specific mutual dependencies are considerably more active in the ENP region, in comparison to other agencies.

When we further analyse the patterns of cooperation by looking at the ENP countries that receive most attention from EU agencies, two core patterns emerge (see Figure 10.2). First, a group of countries that has an advanced integration status is, on average, more integrated into EU agencies' activities. Hence, Georgia, Moldova, Ukraine and Israel are among the ENP countries that have obtained the most access to EU agencies. However, countries that signed their Association Agreement with the EU earlier (Tunisia in 1998, Algeria in 2005, Egypt in 2004, Jordan in 2002, Lebanon in 2006 and Morocco in 2000) than Ukraine (2017), Georgia (2016), Moldova (2016) and Israel (2000) follow the uneven patterns of integration into EU agency activities. Furthermore, empirical evidence does not provide a systematic explanation of the variance in the extent of cooperation. For instance, although Belarus is among the least integrated ENP states, having no formal association status, it has had a working agreement with Frontex since 2009. Security and border protection cooperation between the EU and Belarus is rather developed,

34 See ECDC, 'Partnerships', (2018), https://tickmaps.ecdc.europa.eu/en/about-us/ partnerships-and-networks/partnerships, last accessed 25 October 2018. 
despite low democratic standards. ${ }^{35}$ Hence, the results suggest that the foreign policy hypothesis does not provide a full and systematic explanation of the detected patterns, although it cannot be completely rejected either.

The second pattern reveals that EU agencies working in fields marked by higher levels of interdependence are more open to institutionalized cooperation with the ENP countries (see Figure 10.2). That is, EASA, Frontex, CEPOL and the EMCDDA are most engaged with a group of ENP countries (Moldova, Georgia, Ukraine, Israel, Azerbaijan and Armenia). Such findings in turn provide additional empirical support that these patterns reflecting foreign policy objectives are less pronounced compared to the empirical evidence pointing to the (sector-specific) functional interdependence patterns. This empirical evidence strengthens the functional interdependence hypothesis, as we find that EU agencies working in certain policy fields - that is, security and safety-related areas - are more open to cooperation with the ENP states.

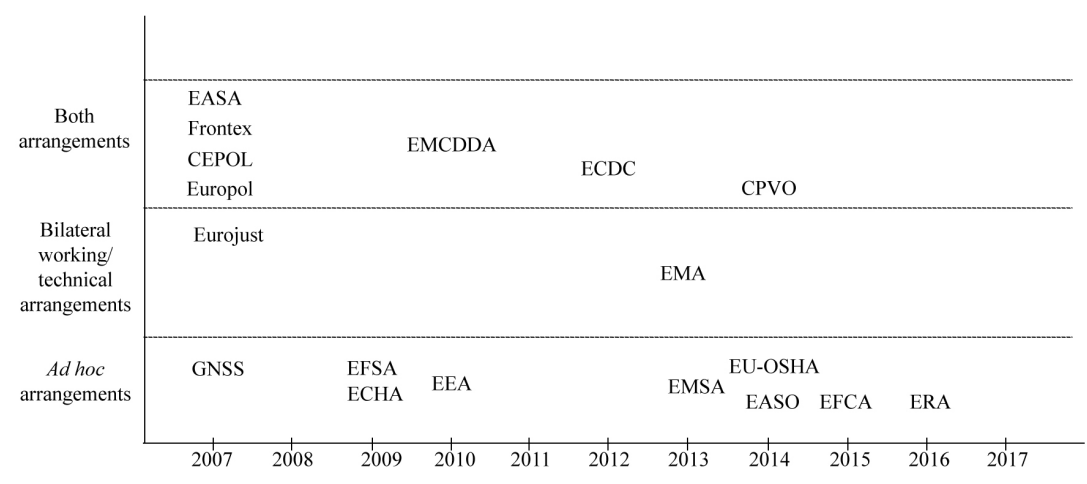

Figure 10.2 The external dimension of EU agencies: cooperation between EU agencies and the ENP partner countries

\subsection{Moderate Cooperation}

The second group of agencies - the European Global Navigation Satellite Systems Agency (GNSS), the European Food Safety Authority (EFSA), the European Chemicals Agency (ECHA), the European Environment Agency (EEA), the European Maritime Safety Agency (EMSA), the European Agency

35 For more on functional cooperation, see Giselle Bosse, 'A Partnership with Dictatorship: Explaining the Paradigm Shift in European Union Policy towards Belarus', [2012] JCMS 3 367, 367-384. 
for Safety and Health at Work (EU-OSHA), the European Fisheries Control Agency (EFCA) and the European Union Agency for Railways (ERA) - are engaged in cooperation with the ENP countries via ad hoc arrangements. However, none of these agencies has established institutionalized ties with neighbouring countries (eg, as opposed to EASA, Frontex, Europol, CEPOL and the EMCDDA). The empirical evidence reveals that the EU regulatory agencies working in the food safety, chemicals, health, environmental protection and railways policy domains form informal transgovernmental networks (as opposed to strong institutionalized ties by, for instance, signing working arrangements with the ENP countries). In the informal transgovernmental networks, EU agencies provide the ENP countries' regulators with individually tailored technical or scientific expertise. In doing so, they contribute to the extension of the EU regulatory state beyond its borders; however, the interaction is organized via ad hoc arrangements in which agencies often contribute to the ENP framework through the TAIEX instrument or are involved in various cooperation activities arranged by DG NEAR.

This finding lends further support to the functional interdependence hypothesis - that is, agencies operating in the policy fields marked by lower interdependencies are expected to be engaged with the ENP countries to a lesser degree than agencies working in the domains of high interdependencies (eg, border control, migration, drug and human trafficking). Provided that the EU and the ENP countries do not manage to establish strong ties in the food safety, chemicals, health, environmental protection and railways domains, the externalities of non-cooperation to the EU are moderate (ie, the EU can still maintain high food, chemical and medicine safety standards within the common market regardless of the level of the safety standards in the ENP countries). In what follows, the section further specifies how EU agencies working in the aforementioned policy fields cooperate with the ENP regulatory authorities.

GNSS has a long and continuous track record of overseeing multiple infrastructural projects in the Eastern and Southern Neighbourhood. It closely works with its local partners to promote the use of the European Geostationary Navigation Overlay Service (EGNOS) and Galileo within the region. Activities are aimed at helping regional countries to embrace and adopt European GNSS technology, with a focus on civil aviation and other transport domains. GNSS is active in providing training sessions and technical assistance to the ENP countries to prepare them for the EGNOS standards.

EFSA is becoming increasingly involved in cooperation with the ENP states. Although EFSA's involvement with the ENP started in 2009, a more sustained cooperation with the EU neighbouring countries via the programme funded 
from the ENP instrument began in 2014. ${ }^{36}$ Through the existing cooperation programme, EFSA aims to improve the ENP states' integration into its core work and responsibilities. In particular, developing and maintaining working relations and scientific cooperation with the EU's neighbourhood is a priority to EFSA for the coming years (EFSA 2014). Through this programme, EFSA is aiming for greater integration of the ENP region. EFSA works with the EU neighbours to transfer EU food safety regulations and consumer safety standards. EFSA's focus is on scientific cooperation with partner countries. To this end, EFSA focuses on exchanging information regarding risk assessment and risk communication practices, and on sharing expertise on handling food crises.

In a similar vein, ECHA has been involved in the EU technical assistance programmes since 2009. Since 2011, ECHA has provided training events for the authorities from the ENP countries upon their ad hoc requests. ${ }^{37}$ Examples include presentations on the EU classification labelling and packaging legislation, the Registration, Evaluation, Authorisation and Restriction of Chemicals legislation and the safety management of chemicals.

EMSA manages training and capacity-building activities and technical assistance projects in the beneficiaries of the ENP states. ${ }^{38}$ Common concerns of the EU Member States and the ENP partner countries bordering the Mediterranean Sea and the Black Sea are maritime safety, maritime security and protection of the marine environment. EMSA is implementing two separate projects for technical assistance (SAFEMED IV and Black and Caspian Seas Region) in the Southern and Eastern Neighbourhood. The core objective is to unify national, European and international stakeholders with the purpose of enhancing the security and safety of marine environment standards. To achieve this goal, EMSA assists the ENP countries in the implementation of the international maritime conventions and helps them to build the necessary administrative capacity to prepare and implement these conventions. The approximation of the ENP countries' national legislation to the relevant EU standards is also an objective of projects implemented by EMSA. EMSA pursues these objectives by providing the ENP countries with training, technical support, tools and services. The specific needs of project beneficiaries are addressed through targeted bilateral technical assistance. Pilot projects in the area of pollution detection and sharing of maritime traffic information

36 See EFSA, 'International', (2018), www.efsa.europa.eu/en/partnersnetworks/ international, last accessed 25 October 2018.

37 See ECHA, 'International Cooperation', (2018), https://echa.europa.eu/about-us/ partners-and-networks/international-cooperation, last accessed 25 October 2018.

38 See EMSA, 'Partnerships', (2018), www.emsa.europa.eu/about/cooperation .html, last accessed 25 October 2018. 
are implemented to incentivize cooperation between beneficiaries and the EU Member States.

EEA has ad hoc cooperation with the ENP partner countries. In the period from 2010-15, it supported the implementation of the Shared Environmental Information System (SEIS) principles and good practices in the countries of the European Neighbourhood, covering EaP countries and Southern Mediterranean partner countries. ${ }^{39}$ The SEIS programme aims to strengthen the steady creation of environmental indicators and assessments, with the ultimate objective of creating knowledge-based policy making and good governance in the ENP partner countries. EEA's support and technical assistance are tailored to the identified national priority areas and therefore target country-specific needs.

EU-OSHA became involved in ad hoc technical cooperation later (in 2014) than other regulatory agencies (eg, EFSA, ECHA and EEA). Furthermore, it pursues different goals from other EU agencies. The core aim of the ad hoc arrangements of EU-OSHA is to establish a single contact point in each country and involve the ENP partner countries in the work of the agency. In so doing, EU-OSHA aims to create a platform for sharing information and best practices with the local safety and health networks. Such links have been established with Algeria, Israel, Morocco, Palestine, Tunisia, Armenia, Azerbaijan, Georgia, Moldova and Ukraine.

EFCA oversees the international dimension of the Common Fisheries Policy (CFP), as well as combating illegal, unreported and unregulated (IUU) activities. ${ }^{40}$ EFCA is obliged to assist the Commission in strengthening operational coordination and regulatory compliance in third countries. To achieve this objective, EFCA participates in ad hoc capacity-building training missions in the ENP countries with which the EU has a sustainable fisheries partnership agreement. The core goal of such missions is to assist countries in the development of inspection of training programmes. Furthermore, EFCA supports the Commission in the framework of the IUU Fishing Regulation. It also assists states in fulfilling their responsibilities by organizing workshops and seminars for national administrations on the application of the Regulation.

ERA only became involved with the ENP partner countries more recently. ${ }^{41}$ ERA oversees the EUMedRail Project (2017-20), which aims to improve the operations and efficiency of the Mediterranean transport system. ERA works

39 See EEA, 'International Cooperation', (2018), www.eea.europa.eu/about-us/ who/international-cooperation, last accessed 25 October 2018.

40 See EFCA, 'International Operations', (2018), https://efca.europa.eu/en/content/ international-operations, last accessed 25 October 2018.

41 See ERA, 'Cooperation', (2018), www.era.europa.eu/The-Agency/Cooperation/ Pages/home.aspx?UniqueID=FAQ\&filterValue1=-1, last accessed 25 October 2018. 
closely with the southern region countries of the ENP (Algeria, Egypt, Israel, Jordan, Lebanon, Libya, Morocco, Palestine and Tunisia) to foster regulatory reforms.

The European Medicines Agency (EMA) constitutes an exception, as it does not cooperate with the ENP partner countries. Health is not an eligible domain of the ENP programme. ${ }^{42}$ Furthermore, EMA cannot invite third country participants as observers to attend Committee and product-related meetings, for confidentiality reasons. EMA has signed a working agreement with regard to pharmaceuticals with Israel only (2013).

\subsection{Limited Cooperation}

The third group of agencies has very limited engagement with the ENP partner countries. For instance, the Foundation for Improvement of Living and Working Conditions and the European Institute for Gender Equality (EIGE) report no activities with the ENP partner countries. EIGE, for example, participates in informal meetings with EU agencies working with the ENP countries to share experiences and good practices. However, EIGE has reported no concrete activities aimed at addressing gender equality standards in the neighbouring regions - for example, ad hoc training or other capacity-building arrangements. This empirical observation provides additional support for the functional interdependencies hypothesis, as the agencies that are least involved (or not at all involved) work in the policy fields that are marked by relatively low interdependencies, such as the European Centre for the Development of Vocational Training and the EU Agency for Fundamental Right. This finding in turn suggests that the promotion of human rights and democratic values (by including EU agencies that oversee these issues) does not play a core role in defining the extent and focus of cooperation with (these) EU agencies.

\section{CONCLUSIONS}

EU agencies introduce a new format of EU external governance that operates beneath the surface of EU centralized decision making. Supranational agencies boost technocratic transgovernmental cooperation by providing access to scientific expertise and know-how experience, as well as by proposing a range of formal and informal cooperation arrangements.

42 See EMA, 'International Activities', (2018), www.ema.europa.eu/ema/index .jsp?curl=pages/partners_and_networks/general/general_content_001848.jsp\&mid= WC0b01ac0580c4d3fe, last accessed 25 October 2018. 
Agencies' contribution to the expansion of the EU regulatory state beyond its borders can follow two different organizational dynamics: cooperation driven by the foreign policy objectives of the EU or sector-specific functional interdependencies. The empirical findings of the study confirm that the external dimension of EU agencies has a differentiated character - that is, different agencies are involved in various regulatory sectors to different degrees. Additionally, the extent to which EU agencies engage in the acquis transfer varies from time to time and from country to country.

The evidence presented in the chapter suggests that this variance predominantly follows the sector-specific interdependence dynamics rather than the overall foreign policy goals of the EU. The strongest, most sustainable cooperation has been established in those policy fields that are by nature transboundary, as predicted by the functional interdependence hypothesis. In line with this hypothesis, issues relating to security, border control and migration take a very prominent role when it comes to the external dimension of EU agencies. The EU agencies working in these policy fields marked by higher functional interdependencies (eg, border control, migration and international crime) establish cooperation with the ENP states earlier than their counterparts working in other policy areas (eg, food safety, chemicals, health, environmental protection and pharmaceuticals). Furthermore, agencies in the field of Justice and Home Affairs (as well as EASA) are open to stronger and more intense cooperation with the ENP states compared to EU agencies overseeing other policy domains.

In contrast, there is little empirical evidence to suggest that cooperation between EU agencies and the ENP partner countries follows the patterns of the ENP countries' integration status with the EU, as the foreign policy hypothesis would predict. We do find that the ENP countries with a more advanced integration status (ie, Moldova, Georgia, Ukraine and Israel) cooperate with EU agencies more than other ENP states. However, we detect little empirical support that this cooperation extends to policy areas beyond security-related issues.

This chapter has provided a systematic overview of the transgovernmental outreach of EU agencies to the ENP countries across different policy domains. It has illustrated that the EU agencies take an active role in the extension of the EU regulatory state beyond its borders. However, multiple research gaps remain to be filled by future scholarship. For instance, we do not know whether the involvement of EU agencies in transgovernmental outreach enables third countries to actually align with EU standards and regulations. ${ }^{43}$ Furthermore,

43 See Karina Shyrokykh and Dovile Rimkute, 'EU Rules Beyond its Borders: The Policy-Specific Effects of Transgovernmental Networks and EU Agencies in 
we know little of what the most favourable conditions for a positive effect of such regulatory involvement in the neighbourhood are. Therefore, future research should assess the effects of EU regulatory transfer by examining whether the involvement of EU agencies in regulatory outreach in third countries can bring the standards of ENP countries closer to the EU's norms.

the European Neighbourhood', https://onlinelibrary.wiley.com/doi/epdf/10.1111/jcms .12883 , last accessed 5 July 2019. 